\title{
A Critical Review of Urban Livability
}

\author{
Nora Osama Ahmed ${ }^{1}$, Amr Mostafa El-Halafawy ${ }^{2}$, and Ahmed Mohamed Amin ${ }^{3}$
}

\begin{abstract}
The term 'Livability' had emerged for a holistic, systemic strategy in an attempt to reverse some of the 20th century urban planning techniques and had applied very broadly; however, ambiguity still characterizes the term. The study tries to give a clear explanation of this term; investigating the linkage between the term 'Livability' and other terms in addition to codifying different studies that are testing new methodologies for analysing cities in terms of being livable. Finally, the paper discusses how to make any built urban environment whether a city, a town or a neighbourhood truly livable.
\end{abstract}

Keywords: Urban Livability, Livability Rankings, Satisfaction, Quality of Life, Well-being

\section{Introduction}

In the 20th century, the city was designed for the citizen; services were within a safe walk, buildings' height was of a human scale and characterized by walkable paths. With the beginning of the modernism era accorded with the car invasion, the city severely affected since modernists rejected the city space, so the city lost its social function and individual buildings became the model. Consequently, a new counterattack began led by Environmental- behaviour design (EBS) researchers who adopted the metaphor of livable city as a way to regain the human scale by reputting people at the centre of the urban equation.

In the 1950s and 1960s, a growing corpus of research began by EBS researchers providing theoretical and empirical foundations for designing for livability. Through their studies, EBS researcherlooked at how people actually use and perceive cities and then often developed this information into design guidelines and recommendations. As a result, in the 1980s and early 1990s, the term 'livability' became a popular topic, and many responses emerged, represented in the initiating of planners to study the shift in development patterns from the decline of urban centres to rapidly growing suburban areas. Besides, the increase in the prevalence of annual surveys that ranked the world's most livable cities and boosted the terms' popularity, such as the Mercer Worldwide Quality of Living Survey, and the report of World's Most Livable Cities.

This study exemplifies an attempt to recognise these responses, in order to provide a well understanding of this term and reach a profound definition that truly reflects livability.

\section{Materials and methods}

The aim of this critical review paper is to provide a clear explanation of this term. It draws the attention to the importance of the term 'livability' in bringing people back to the urban equation. Thus, misrepresenting the term with other associated terms dilute its accurate meaning 
and deviate its principal goal. This is done through a systemic review in which the paper first provides a critical literature review of the most relevant definition for urban livability, to inform a comprehensive understanding of 'Livability'. Next, the paper investigates the linkage between 'Livability' and other related terms. A review of the livable cities rankings is discussed to investigate their credibility and to identify essential philosophies in establishing the proper livability index. Finally, the paper concluded that 'Livability' isn't as accepted a hard term and can be realistic if not just regarded as only a quantifiable result of satisfactory and appealing urban condition yet in addition of individuals' recognitions about urban life.

\section{Results and discussion}

\subsection{Urban livability definitions: a look at the literature}

\subsubsection{The Debate of 'Livability' Definitions' in the Built Environments}

Despite diverse efforts for reaching 'livability' and its widespread use, it can be said that there is no single agreed upon the term not only for its definition but also for its spelling word. 'Liveable' is the favoured spelling for the British while 'Livable' is the favoured spelling for the American, and is picking up acknowledgment around the globe [1]. The term "Livability" as a noun literally means "the property of being livable" [2], also it can be defined as "suitability for human living," and as an adjective 'Livable' means "fit or suitable or acceptable to live in or with," it can be explained as well as "can be lived" [3]. However, the degree of suitability depends on the community-specific values and context as the locally dominant economic, social, and cultural backgrounds because the personal feeling or the desire of the resident of a particular place is what governs the degree of 'livability' of this place $[4,5,6$. Hence, 'livability' in the US stands for 'quality of life' and 'wellbeing', but 'livability' in the UK, provides a more precise meaning connected to the cleanness, safety, and existence of plants on the local surroundings. "Livability is a behavior-related function of the interaction between environmental characteristics and personal characteristics," [7] see Figure 1. Thus, the more we identify the subjective experience of living in particular places, the more we identify the key features of 'livability' and understand how to assess this concept [8].

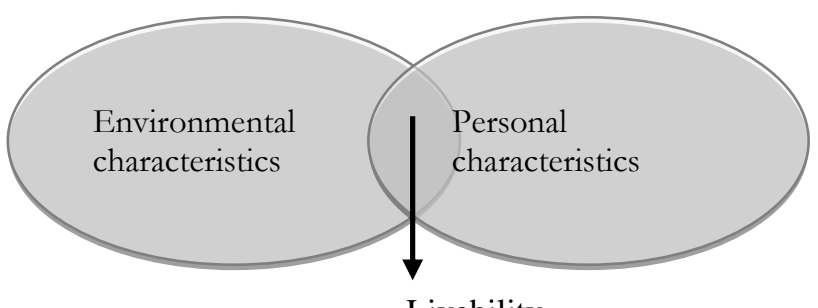

Livability

Figure 1. Show the behaviour-related function of 'Livability' [7].

Thus, many academics perceive 'Livability' as a subjective concept and termed 'Livability' by different expressions related to inhabitants' impression and perception including 'vitality', 'liveliness', and 'sense of belonging' to mention a few. Although these expressions are closely tied to 'livability', they are not its alternative word. 'The original meaning of livability described conditions in neighborhoods where residents live relatively free from intrusions; whereas, sense of 
belonging is the psychological or emotional dimensions obtained from living in a particular place such as a neighborhood, on a street or in a building, while vitality is the presence of other people within close proximity and how this influences the functionality and desirability of public places" [9]. Despite this distinction, on the words of [10], the first scientific approach to vitality took place in social sciences and humanities called as "livability." In fact, Liveliness' and 'vitality' are two interrelated expressions, have been synonymously defined as "the state of being when you are full of life and energy" [3]. This interrelationship was from the beginning according to [10] since the term 'vitality' used exclusively in the popular literature, alluding to liveliness and vividness. In the urban environment, 'vitality' means the variety of activities in the public domain and adjustment for urban spaces under the framework of behavioural bases.

It should be said that, all these words as 'vitality', 'liveliness', and 'sense of belonging' are qualities to be met in any livable place, rather than synonyms for livability'. What makes them mistakenly used instead of the term 'livability' is working in the context of behavioral bases as mentioned previously in [7], which is the cornerstone of understanding livability'.

\subsubsection{A Comprehensive Understand of 'Livability'}

In spite of the different attempts to understand 'livability' as a term whether by setting livability rankings or indices, but the term remains difficult on the words of [11] saying "I do not believe there is a single silver-bullet answer to creating livable cities." It is a deeper term that covers more than just a good 'standard of living' or good 'quality of life' since the city is a set of interrelated relationships that incorporate services such as parks and green space beside incorporate cultural offerings, job prospects, economic dynamism, and a feeling of safety. In order to achieve 'livability' there is a need to plan, design, manage these relationships, and in the words of Jan Gehl need to change the mindsets about urban planning and living. The literature clearly showed that 'livability' not only inherent in environmental characteristics but most importantly, it incorporates a social dimension regarding how people interact within local environments [12, 13]. Noting that, people's recognition of 'livability' varies between groups and individuals according to different and shifting perceptions, values, and desires. 'Livability is a changing process and about paying attention to local contexts... an important question should be asked when talking about 'livability' which is 'for whom?"' [11]. In thinking about how to create 'livability' in places as different as Philadelphia, Dhaka, and Copenhagen, the answer definitely will be extremely different. Different people understand 'Livability' according to different things $[14,15]$. The term 'livability' has progressively broadened to include a range of different issues that are underpinned by a common set of guiding principles: accessibility, equity, safety, comfort, available services, walkability, transit, and participation that give substance to the concept of livability.

\section{2 'Livability' and related concepts}

It can be noticed in reviewing the term 'Livability' in the literature that several terms are used interchangeably with this term as 'sustainability', 'well-being', 'satisfaction', 'quality of life' and 'happiness' among others, to the extent that they are used as synonyms. This created a kind of uncertainty about what 'Livability' mean precisely, it became a very general term that permits to incorporate an array of different meanings to different people and a variety of fields is covered by the term. In fact this term does share terms like quality of life, well-being, and life satisfaction all 
across; however, the term 'Livability' is still characterized by more than expressing a place and its living conditions; it imitates the perception of the people about this place and whether it is suitable for living or not. As a result, recognizing the relationship between livability' and other terms became more crucial than reaching a consensus definition for them; detecting areas of contradiction and integration $[4,16,17,18]$.

\subsection{1 'Livability' Versus 'Sustainability'}

'Sustainability' and 'sustainable development' are concepts that closely aligned with 'Livability', and sometimes utilized mutually in the literature. They are likened to being hard to pin down either to be realized theoretically or to be applied by the planner practically and implemented at local scales. However, 'Sustainability' is more distinguished for having an accepted, commonly used definition stating “...development that meets the needs of the present without compromising the ability of future generations to meet their own needs" [19].

'Sustainability' is about 'there and later'; acting as a constant beacon with philosophical visions, whereas many scholars treat 'livability' as a term that focuses on 'now and here'; paying consideration to the active physical conditions and interventions. That is what makes 'livability' a fluid concept because it changes based on conditions of the context and provides dynamic useful translation to this vision. So, these two terms reinforce rather than deny each other; in which 'Livability' is an array of interventions that people behave in the context in the present day, these interventions achieve 'sustainability' in the long term [18, 20, 21]. This vision is clearly illustrated in van Dorst's model; see Figure 2 who assumed that livability is a subset of sustainability (i.e. depending on the 'triple-bottom-line' sustainability model). Thus, it cannot be considered as an independent variable, and no aspect of livability is contrary to sustainability outcomes. Livability studies only overpass sustainability studies on taking more consideration of human and social factors. The model places livability within the broader sustainability agenda; differentiating between the longer-term and global perspective of sustainability and the more confined, and direct address of livability [22].

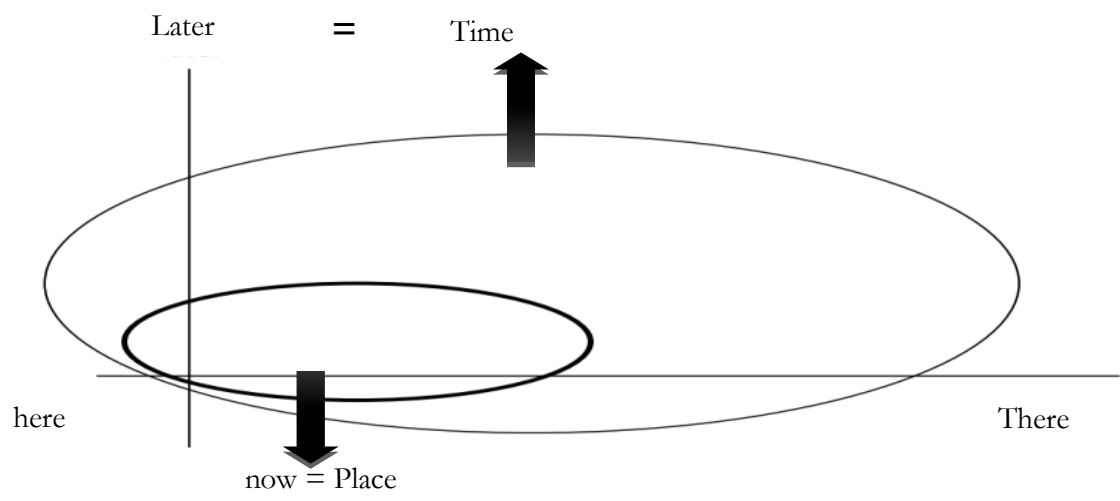

Figure 2. Illustrate 'Livability' is a sub-set of 'Sustainability' [22].

Scholars have articulated that sustainability is based on 'three pillars' economy, equity and environment $[23,24,25]$; however, in studies that are related to sustainability, it is found that the 
environment pillar used to dominate. This is because its variables are less demanding on the measure; normally relate straightforwardly to the estimation of the based surroundings and performance standards. For instance, the studies in [26] relatively measure the amount of greenhouse gas emanations generated, water consumption, or the value of electricity; however, the study neglected the satisfaction of the residents. On the contrary, Livability studies are unique in recognizing that the social factors are equally important as economic and environmental aspects. In light of this, livability can be perceived as a critical component of sustainability; a specific section of the 'triple-bottom-line' model that prioritizes the human, social factors 'lens' over the economic pillar and the environment pillar [27], see Figure 3.
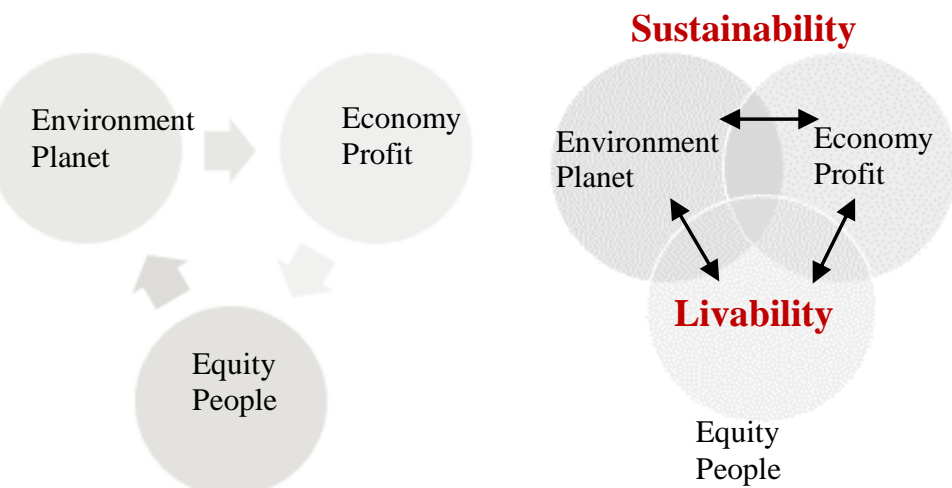

Figure 3. Illustrate Livability acts as an Integral part of Sustainability. Prioritizing People and Social Equity over the other pillars [27].

\subsection{2 'Livability' Versus 'Quality Of Life', 'Satisfaction', 'Well-Being'}

As 'Livability' used to be linked to 'Sustainability', alternatively there is an increasing amount of research that makes an important nexus between 'livability', 'quality of life', 'satisfaction', 'wellbeing', and other related concepts. The study adopts the idea of placing 'Livability' in comparison to all these related concepts and terms, in order to understand it in a more appropriate way. Actually, the urban planning field used 'quality of life' to express the term 'livability' and some of the time these two terms are reciprocally utilized. However, there is a distinction between these two terms. "Livability' is the presence and quality of the amenities of the built and natural environments while 'Quality of life' is the user experience of those amenities and any associated health benefits. So, where 'livability' is concerned with the transportation choices a community offers its residents, 'quality of life' refers to the associated health benefits received by residents who have the choice to select more active travel modes." [28]. 'Livability' refers to the contribution of the urban settings that motivate all these related concepts as 'quality of life' or 'well-being' of residents $[28,29]$. It is a term that tends to match between people and their living environment through interventions, which represents the incremental steps collectively increase the potential for longer-term paces toward sustainability. In other words, in order for communities to be sustainable, they must be a preferred place for people; when the environment provides a suitable environment within which the individual lives, it becomes a livable environment, but once the 
individual in this environment feels with satisfaction and well-being, the term 'quality of life' is introduced, see Figure 4.

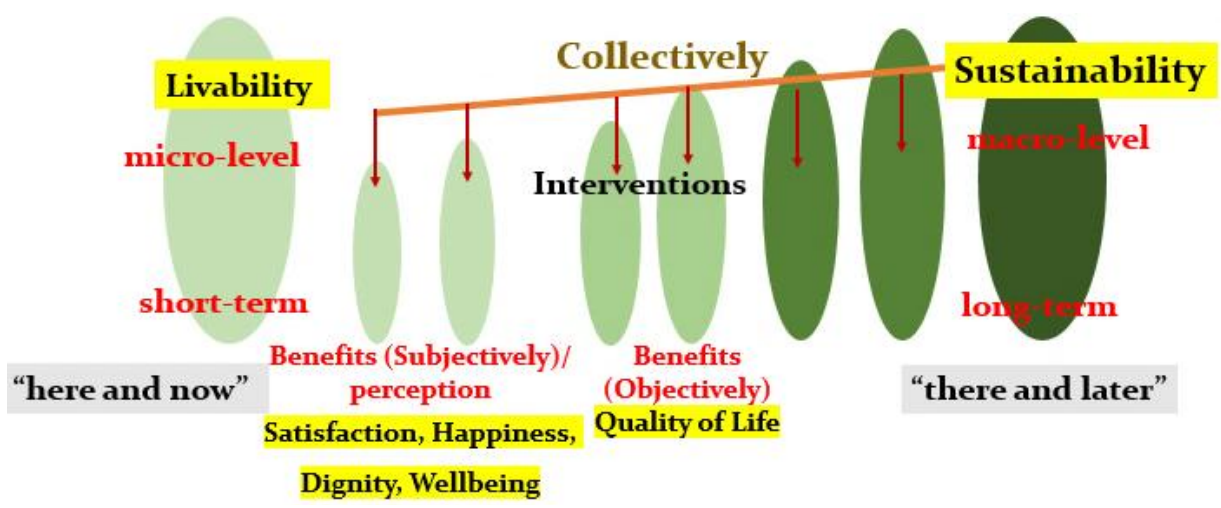

Figure 4. Illustrate 'Livability' in comparison to all these related concepts, based on a literature review and represented by the researcher.

Moreover, healthy communities and livability are closely connected because the built and natural environments where people live and characterized by social, economic, and political variables determine understanding health [30]. Therefore, the determinants of health and livability is profoundly related, for example, the accessibility to healthy foods, jobs and education, number of walk trips, lower speed limits, social engagement, air and water pollution are all related to health, nevertheless, the exact nature of the relationship between healthy neighborhoods and livability has not been determined yet. However, it could be understood by the health map, see Figure 5 developed by Barton and Grant based on the work of Dahlgren and Whitehead [31] this map demonstrates the health consequence of the manner of development activity in our built environment; trying to solve the indirect and complex links between health and settlements. In fact, placing people at the heart of the map and reflecting the different facets of a human settlement in the series of spheres help distinguish urban development processes and contribute to not only health impact assessment, but also livability and sustainability. For instance, constructing a new road in the built environment changes the pattern of human activity as travel behavior and destinations affect the local natural environment (i.e. air contamination) and the global ecosystem (i.e. greenhouse emissions). It also influences people's lifestyle decisions (i.e. the probability of strolling alternately driving) [32]. In this sense, 'Livability' constraints 'sustainability' and other related concepts, but does not directly orchestrate it. Instead, through a series of 'livable' involvements; focuses on the experience of place; where people live, how they travel to work, and how they interact together and their surroundings, the outcome will accomplish 'quality of life' presently, and 'sustainability' later on. "The lively city is the starting point for holistic city planning that encompasses the vital qualities that a city safe, sustainable and healthy" [20]. For that reason, 'Livability' acts as the cornerstone of all these concepts; it is the instant action taken on the ground to achieve the equilibrium between people and the living environment. The more the interventions directly related to people, the more the quality of life is affected and terms as wellbeing, happiness, and satisfaction appeared, but when the interventions related directly to the living environment, sustainability is affected. Most importantly, depending on this instant action, three important things are determined, firstly, whether the built environment will be 'sustainable' 
on the long-term or not, secondly, will the 'quality of life' be achieved now and users will feel with satisfaction, happiness and well-being or not. Thirdly, will communities be 'healthy' and public health prospered or not.

Figure 5. Conceptual model of the determinants

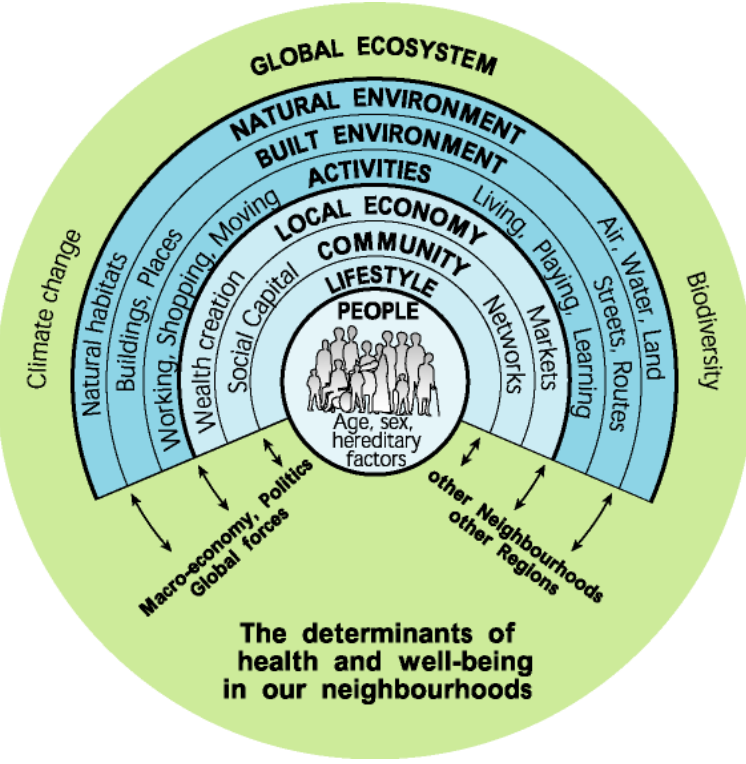
of neighbourbood health and livability [32].

\subsection{Approaches for measuring 'livability'}

The appearance of the term 'livability' in the wider literature during the 1980s received attention on the rise of the environmental concerns and the expanding rivalry among world urban communities to draw in outside ventures and lift their economies. Seeking livability' had become a vital urban concern worldwide, many actors work towards maintaining, or improving a city's degree of 'livability', that made assessing the concept of 'livability' in urban planning and design a necessity. Nevertheless, a reasonable and a pivotal question is raised in [33] saying "Who decides how livable a city is, and just how accurate can they possibly be? News organizations think tanks, academics, and others produce a raft of rankings to tell us exactly which cities are the most livable and which are not."

An annual list of cities under an informal name "The World's Most Livable Cities" was created, this list rank cities according to its living conditions. There are actually three big names in livability' ratings: the Economist Intelligence Unit's livability Ranking (EIU), Mercer Quality of Living Survey, and Monocle's magazine 'Most Livable Cities Index'. These rankings work under quantified criteria and then weighted and scored. The EIU livability ranking compares 127 world cities and publishes annual reports listing the top 10 best and worst cities in terms of livability, and it is considered the most inclusive and widespread of all livability-ranking systems. This is most likely because EIU highlighted cities that have achieved significant progress in their livability over the last 5 years, in addition to; it depends on collecting data and measuring tools that incorporate unrefined measurable data, public opinion surveys, and interviews with a comprehensive range of international professionals, city officials, and urbanites. Contrasted with EIU, the Mercer Quality of Living Survey mainly gives a premium on quality of living in over 460 cities worldwide, giving 
an aide for organizations to choose the appropriate place to open offices, and how much wages to pay for workers. The third name in livability' ratings is 'Most Livable Cities Index' occurred in Monocle's magazine that created a rating system for the great common 25 praised capitals around the universe.

On the other hand, there are livability ranking tools that link livability' with the 'quality of life', including EU Urban Audit, the International Living Quality of Life Index, the United Nations Human Development Index, and Forbes, which provides specific livability ranking for American cities and specifically focuses on economic opportunities, job growth, living cost, and cultural exercises. Moreover, some livability measures link 'livability' with 'well-being' as the Australian Unity Well-being Index measures personal well-being (i.e. indicators are community inclusion, safety, the standard of living, and health), the national well-being (i.e. indicators are environment state, national security, social conditions, and business). Added to OECD Better Life Index established by the Organization for Economic Co-operation and depends on three distinct domains (i.e. sustainability, material conditions, and quality of life).

\subsection{1 'Livability' Ranking Critical Perspective}

Although these rankings had become as the secret code of the success of urban planning among cities worldwide, there is no denying that they endure various lacks. The first is the personal judgment in quantifying these aspects as for health care why it should matter for twice the amount of education, or ignore the cost of living entirely. Secondly, the aforementioned 'livability' indices had branded cities and mobilized government officials to examine their socioeconomic and environmental conditions to compete on a global scale; assessing 'livability' at a comprehensive level instead of the local scale as residential areas. The third shortcoming is that city rankings focus merely on objective factors, such as transportation, but actually, city is more than that, it is made of people who live in it so the perceptions of and the satisfaction of people with their cities must be taken into consideration which is related to subjective factors. Therefore, it is not only the presence of the facility as transportation but also the quality and how people feel about it. 'Livability' indices make an effort to reflect the objective part; however, they fail to reflect the subjective part; experiences that are important to residents of a city, not to the experts who create 'livability' indices.

The study prepared in [34] illustrated the relationship between the objective and subjective factors in trying to answer the question if there is an overlap between the objective factors presented in popular Mercer city ranking of 'livability' and the subjective factors presented in survey data measuring city satisfaction. The study found that there is a fragile correlation between Mercer 'livability' city ranking and survey data of city satisfaction, for example, residents in some cities are satisfied and their Mercer 'livability' index is high, these cities are Amsterdam, Copenhagen, Barcelona, Luxembourg, Hamburg, Helsinki, Munich, Stockholm, and Vienna. On the other hand, people are slightly happy in highly ranked cities by Mercer as Berlin, Brussels, Dublin, Lisbon, Madrid, and Paris, while people in Athens are not very satisfied. However, Mercer ranked Athens only a little lower than the normal, same as Zagreb Mercer rating which is much lesser than Athens and people are very satisfied, see Figure6. 


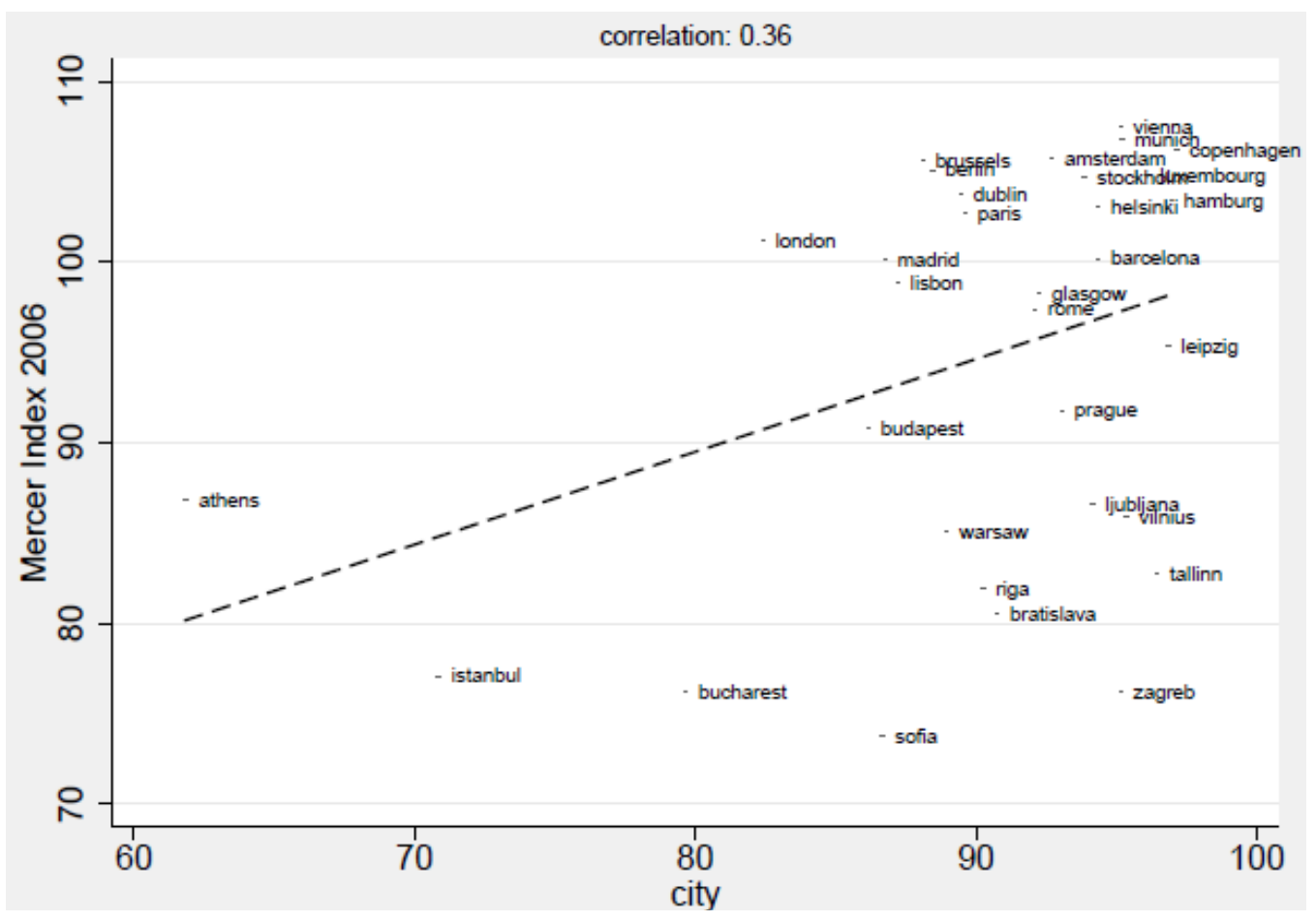

Figure 6. Illustrate Mercer index against city satisfaction [34].

In this manner, the objective quality of life represented in the Mercer livability' ranking is incompatible with the subjective quality of life symbolized people's satisfaction. 'Livability' rankings are created by specialists based on normative ideals that they used to allocate weights to the objective characteristics to produce the 'livability' index, it only expresses specialists' viewpoint while how inhabitants who live there feel is ignored, so the ranking mispresent the current situation and can be considered as a hollow model. The appropriate understand and assessment of 'livability" is simplified in [34] declaring three distinct concepts for the quality of life "normative, objective, and subjective" and asserting on the need to remove the overlaps between them. The normative quality of life refers to models what philosophers and experts consider a good life, while the objective quality of life describes world objective qualities, such as the GDP, which is the Gross Domestic Product that measures market production expressed in money units, median income, housing prices, and crime rates. On the other hand, subjective quality of life states what people feel, as happiness that can be measured using questions by simply asking people, for example in assessing objective quality as transportation aspect, it will be weighted in a normative way according to the experts' criteria, without neglecting the subjective qualities symbolized in citizens' priorities and needs, see Figure7. 


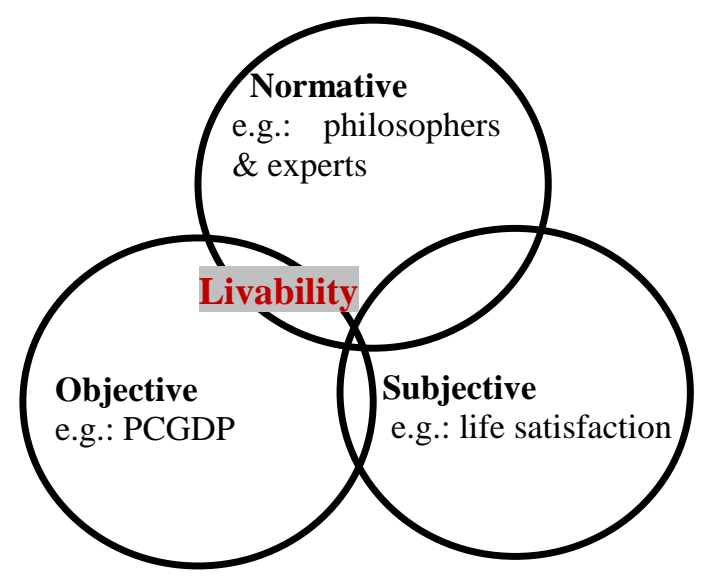

Figure 7. Show 'livability' in relation to normative, objective, and subjective qualities of life [34].

\subsubsection{Confronting 'Livability' Indices Deficiencies}

Different systems had been established to monitor the quality of life through identifying indicators that influence the 'livability' of a neighborhood, city, and a country. These systems used carefully selected social, economic, and environmental indicators and helped to gauge progress and to make comparisons between and among different cities, countries, and regions. However, these 'livability' indices adopted the original meaning of the term livable' when it enters the English language in the seventeenth century with the meaning likely to survive', neglecting the transformation that happened to the term within fifty years, the definition comes to mean 'suitable for living in' [1]. The former definition creates a 'viable city', while the latter one creates a livable city'. 'Livability' Indices paid attention to the prerequisite for any resident to live in any place, but a livable city is more than that. Maslow's (1954) hierarchy of human needs provides a useful framing device for assessing the success of urban planning discipline, and their general livability. Livability studies endeavor to address two key inquiries, the first is 'How do people expect to and actually fulfill their needs and wants in the urban context?', and the second is 'How do we differentiate between a truly human "need" versus luxuries we "want"?' [27]. People need to satisfy their basic needs as shelter or food, but once they fulfill their basic needs, a higher level of needs created related to psychological needs such as creativity, innovation, and so forth. In fact, understanding who you are and what you are looking for determine a livable city, so a livable place for a group of people is not necessarily also livable for other groups. Therefore, the indices cannot be in general and should be specialized; studying a community with young, single, and rich people as New York City will definitely be different than studying a middle-class, middle-aged and with kids as Dallas, see Figure 8. 


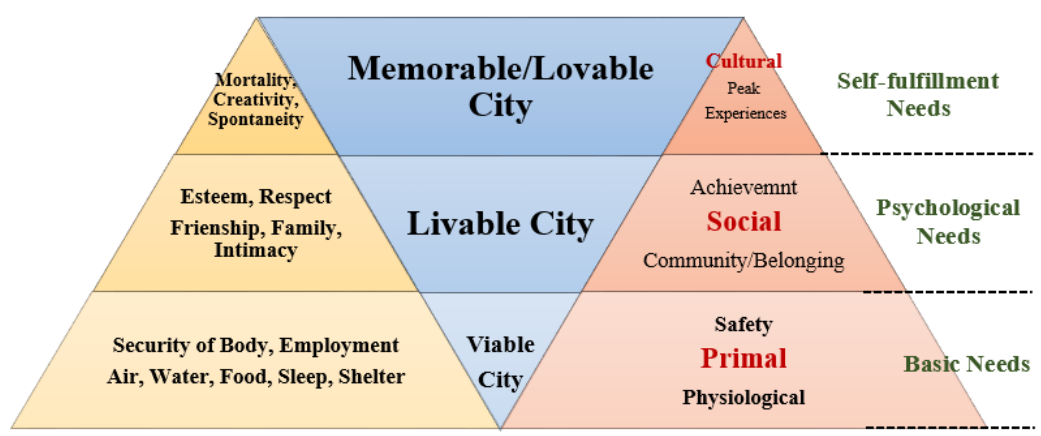

Figure 8. Show the relation between Maslow's bierarchy of needs and its effect on the city, based on literature revien and developed by the researcher.

These rankings targeted at businesspeople and aimed at attracting businesses and industries; however, are not even used for economic predicting or setting the policy of the government, rather than for measuring the degree of ease in the city whence of goods and facilities such as health care, clean water, education, apartments, computers, foodstuff, clothing, etc. and that actually what made these rankings attract extensive media coverage, and become a popular topic of discussion and so spread out in magazines and newspapers. In this way livability' rating assessed cities from the perspective of the 'standard of living', the latter refers to better health care, educational standards, and a more comfortable environment that comes with higher incomes. Whilst, livability' should be concerned with the quality of everyday social life, the interactions that we have every day and the quality of those interactions [35].

It has become a necessity to reach appropriate 'livability' indices that overcome the deficiencies in the existing livability' ratings and truly measure the built environment as efficient mass transit, bike lanes and networks, child-friendly city spaces, and mixed-use urban fabrics. Livability ratings should pay attention to city center revival, compact neighborhoods, humanscaled public places where people can gather to participate in farmers' markets, festivals, outdoor cafes, and community life. An appropriate livability' rating is the one that guides experts and city officials towards building healthy and social cities as well as will be ecologically sustainable. Instead of assessing the livability of a neighborhood by its high standards of living, it should be assessed by its social life as well and try to reach a balanced state between the rich social life in a poor neighborhood with a bad sanitation but distinguished by an inclusive environment and a richer one with well-arranged drainage systems [35]. Some non-profit organizations in the US as the Project for Public Spaces (PPS) [36] and the American Association of Retired Persons (AARP) [37] had worked on creating this applicable index, see Table 1. Standing on the belief that there is no one definition of livability, it is something that everybody wants, but it does not mean the same thing to all people- it means different things to different people. In consequence, PPS and AARP created their livability index by implying the abovementioned concepts adopted in [34].

The normative aspects implemented the American Institute of Architects (AIA)'s ten livability' principles embraced by the partnership for livable communities based on the six livability' principles. "1- Promote transportation choices, 2- increase housing affordability, 3enhance economic development, 4 help existing societies through strategies as transit-oriented, mixed-use development and parcel recycling, 5- coordinate policies and leverage investment to overcome obstacles to collaboration; institutionalizing people-centered approaches in government 
and civil society; spread the culture of putting people first across city departments, 6- value communities and neighborhoods by empowering healthy, safe, and walkable environment" [38]. Objective aspects represented in the urban features of a public space according to PPS assessments, whereas for AARP it will be the built environment of a neighborhood. Subjective aspects state what people feel, as happiness; measured using questions by simply asking people.

The Project for Public Spaces (PPS) adopted a placemaking approach to livability; defining placemaking as "the art of creating public 'places of the soul,' that uplift and help us connect to each other". Based on its own livability research as well as the quality of life research, Project for Public Spaces has developed a simple graphic that describes a model for assessing characteristics of livable places. These attributes are characterized by two qualities; tangible, statistical aspects that reflect the common issues that people tend to identify when they talk about livability in their communities; considered by PPS to be "essential ingredients of a place - uses and activities, comfort and image, access and linkages, and sociability". As well as, intangible qualities that people feel toward a place or a neighborhood (i.e. safe, fun, charming, and welcoming) [39]. The Placemaking Diagram had been supported in literature as an effective technique to implement 'livability'; its integration to the 'livability' principles emphasizes its starring role in creating livable communities and places where people want to spend discretionary time [40].

On the other hand, the American Association of Retired Persons (AARP) Public Policy Institute supports the livable urban environment by developing AARP livability' Index an online instrument to quantify community livability on a size of 0 to 100 , with higher scores speaking to livability that is more prominent. All Users including policymakers can explore the Index by inserting their address, ZIP Code, and their city, or county and get an overall score. In addition to, a score for each of seven major livability categories: affordable and accessible housing, accessible neighborhood to life, work and play, safe and convenient transportation options, environment with clean air and water, health with regard to influencing health behaviors, community engagement with civic, economic, social involvement, and inclusive and possible opportunities. For each category, the Index evaluates current conditions as well as policies and programs that can enhance community livability over time, includes 60 indicators with 40 metrics measure the livability of communities now and then 20 policies measure livability progress over time across these seven categories. Users also have the option to modify the index according to their priority; paying more attention or less to the livability features. The Livability Index website depends on giving scores to different resources to evaluate livability generally at the neighborhood level for the entire country; which helps consumers and policymakers make a change in their communities to make it livable. AARP index targeted creating livable communities for all ages with special reference to older adults (i.e. 50 years and above) on the viewpoint that this age group is with high sensitivity to affordable places due to their fixed incomes as well as their pressing need for transportation and housing to be accessibly caused by their mobility challenges. Thus, satisfying their special need will ensure taking the needs of other ages into consideration, and create great neighborhoods for All Ages. Each category provides a resource in the community trying to answer the question of how to allow residents to age in a place.

Table 1. Illustrate organizations attempt to incorporate normative, objective, \& subjective aspects by applying 'livability' principles, based on literature review and developed by the researcher

\begin{tabular}{|l|l|ll|}
\hline $\begin{array}{l}\text { Non-profit } \\
\text { organizations }\end{array}$ & Project for Public Spaces (PPS) & $\begin{array}{l}\text { American Association of Retired } \\
\text { Persons (AARP) }\end{array}$ & \\
\hline
\end{tabular}




\begin{tabular}{|c|c|c|c|c|}
\hline \multicolumn{5}{|l|}{$\begin{array}{l}\text { Points of } \\
\text { Difference }\end{array}$} \\
\hline $\begin{array}{l}\text { Normative } \\
\text { aspect }\end{array}$ & \multicolumn{4}{|c|}{$\begin{array}{l}\text { Six 'livability' principles \& users can adapt weights in the Index according to } \\
\text { their priorities }\end{array}$} \\
\hline $\begin{array}{l}\text { Objective } \\
\text { aspect }\end{array}$ & \multicolumn{2}{|c|}{$\begin{array}{l}\text { Applying Placemaking Diagram } \\
\text { on a small area around where } \\
\text { people live or work, one that is } \\
\text { probably no larger than a } \\
\text { downtown or a neighborhood. }\end{array}$} & \multicolumn{2}{|c|}{$\begin{array}{l}\text { Applying AARP livability' Index on a } \\
\text { scale of Neighborhood level }\end{array}$} \\
\hline $\begin{array}{l}\text { Subjective } \\
\text { aspect }\end{array}$ & \multicolumn{2}{|c|}{$\begin{array}{l}\text { Place Diagram tool help people } \\
\text { judge if the public space is a } \\
\text { living space or not } \\
\text { WHATAARESA } \\
\text { GREAT PACE? }\end{array}$} & \multicolumn{2}{|c|}{$\begin{array}{l}\text { An online tool designed to help } \\
\text { communities better serve the nation's } \\
\text { aging population }\end{array}$} \\
\hline $\begin{array}{l}\text { How 'livability' } \\
\text { is defined }\end{array}$ & \multicolumn{4}{|c|}{$\begin{array}{l}\text { There is no one definition of livability, it is something that everybody wants, } \\
\text { but it does not mean the same thing to all people- it means different things to } \\
\text { different people }\end{array}$} \\
\hline Target & & \multirow{2}{*}{\multicolumn{2}{|c|}{$\begin{array}{l}\text { People aged } 50 \text { years and above } \\
\text { Create Great Neighbourhoods for All } \\
\text { Ages }\end{array}$}} \\
\hline Goal & \multicolumn{2}{|c|}{ Identify what makes a great place } & & \\
\hline \multirow{4}{*}{$\begin{array}{l}\text { Criteria } \\
\& \\
\text { Categories } \\
\& \\
\text { Indicators }\end{array}$} & 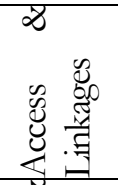 & $\begin{array}{l}\text { Accessible/convenien } \\
\text { t/walkable/readable/ } \\
\text { connected/proximity } \\
\text { / continuity }\end{array}$ & 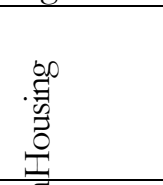 & $\begin{array}{l}\text { Housing Accessibility / } \\
\text { Options / Affordability / } \\
\text { Livability Commitment }\end{array}$ \\
\hline & 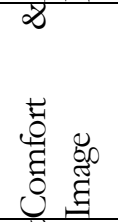 & $\begin{array}{l}\text { Safe/clean/green/wal } \\
\text { kable/sittable/spiritua } \\
\text { 1/cha- } \\
\text { rming/attractive/ } \\
\text { historic }\end{array}$ & 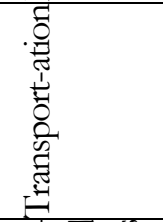 & $\begin{array}{l}\text { Convenient } \\
\text { Transportation Options / } \\
\text { Safe Streets / Accessible } \\
\text { System Design / } \\
\text { Livability Commitment }\end{array}$ \\
\hline & 兽: & $\begin{array}{l}\text { Fun/Active/vital/ } \\
\text { special/real/useful/ } \\
\text { indigenous/celebrator } \\
\text { y/ sustainable }\end{array}$ & 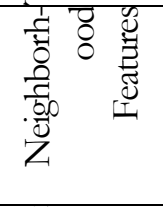 & $\begin{array}{l}\text { Destinations Proximity / } \\
\text { Mixed-use / Compact / } \\
\text { Personal Safety / Quality } \\
\text { / Livability Commitment }\end{array}$ \\
\hline & 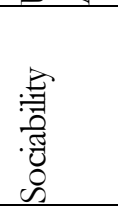 & $\begin{array}{l}\text { Diverse/stewardship/ } \\
\text { cooperative/neighbou } \\
\text { rly/ } \\
\text { pride/friendship/inter }\end{array}$ & 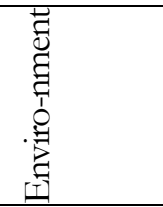 & $\begin{array}{l}\text { Water Quality / Air } \\
\text { Quality / Resilience / } \\
\text { Energy Efficiency / } \\
\text { Livability Commitment }\end{array}$ \\
\hline
\end{tabular}




\begin{tabular}{|c|c|c|c|c|}
\hline & & \multirow[t]{3}{*}{ active/ welcoming } & 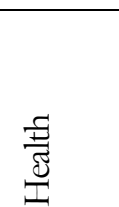 & $\begin{array}{l}\text { Healthy Behaviours / } \\
\text { Access to Health Care / } \\
\text { Quality of Health / Care } \\
\text { Livability Commitment }\end{array}$ \\
\hline & & & 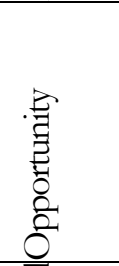 & $\begin{array}{l}\text { Equal \& Economic } \\
\text { Opportunity / Education } \\
\text { Multi-generational / } \\
\text { Communities Local Fiscal } \\
\text { Health / Livability } \\
\text { Commitment }\end{array}$ \\
\hline & & & 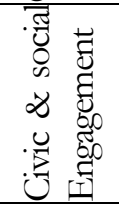 & $\begin{array}{l}\text { Internet Access / Civic } \\
\text { Engagement / Social } \\
\text { Engagement Equal Rights } \\
\text { / Livability Commitment }\end{array}$ \\
\hline
\end{tabular}

In evaluating these attempts, they considerably translated 'livability' concept since they address the three main deficiencies of Livability rankings. Firstly, they profoundly reflect the concerns and needs of a local community, because AARP and PPS adopted approaches that directly connected 'livability' concept to a specific place utilized by people in communities. They are working on a manageable and relevant scale; a small area around where people live or work, one that is probably no larger than a downtown or a neighbourhood. This small-identified place well defined the problems as PPS argued, "When "closer to home" problems are defined, residents of an area are not only better able to identify priorities, but they are also more likely to become involved in a place's improvement" [39]. AARP 'livability' index and the Placemaking Diagram solve the shortage of the broad discussion of livability or the enormous coverage of a geographic area to develop practical strategies that superficially address local community concerns. Secondly, well identified the three distinct concepts of quality of life; in assessing the objective quality of the built environment as housing, it will be weighted in a normative way according to the livability principles, without neglecting the subjective qualities embodied in citizens' priorities and needs. Most importantly, AARP livability' Index or PPS diagram tool permit users to assess the 'livability' of their communities; depending on their own preferences, citizens give scores or determine actions to retrieve their livable community. Thirdly, AARP \& PPS Livability Index adopted an objective flexible approach in weighting livability attributes; it is up to each community to choose the relative weight of each attribute according to its different socioeconomic situations, living conditions, demographic makeup, geographic location, and political context, so any community can apply the index, though, create a unique community, see Table 2.

Table 2. Illustrate How AARP \& PPS Livability Index Address 'Livability' indices' deficiencies, based on literature review and developed by the researcher.

\begin{tabular}{|l|l|l|}
\hline $\begin{array}{l}\text { Livability Indices } \\
\text { Points of Difference }\end{array}$ & Livability ranking & AARP \& PPS Livability Index \\
\hline Target Group & Global scale & Local Scale \\
\hline
\end{tabular}




\begin{tabular}{|c|c|c|c|}
\hline $\begin{array}{l}\text { How } \\
\text { descriptors } \\
\text { weighted }\end{array}$ & $\begin{array}{r}\text { 'Livability' } \\
\text { are }\end{array}$ & $\begin{array}{l}\text { Subjective Rigid Approach } \\
\text { Primarily based on personal } \\
\text { judgment; quantifying these } \\
\text { aspects by specialists' viewpoint }\end{array}$ & $\begin{array}{l}\text { Objective Flexible Approach } \\
\text { It is up to each community to } \\
\text { choose its own priorities }\end{array}$ \\
\hline $\begin{array}{l}\text { 'Livability' } \\
\text { Assessment }\end{array}$ & & Standard of living & Quality of everyday social life \\
\hline $\begin{array}{l}\text { Strategy for } \\
\text { 'Livability' }\end{array}$ & applying & $\begin{array}{l}\text { Top-Down Approach } \\
\text { Setting practical strategies to } \\
\text { address 'livability' on a local } \\
\text { scale }\end{array}$ & $\begin{array}{l}\text { Bottom-Up Approach } \\
\text { Improvement of specific places to } \\
\text { produce livability success on a } \\
\text { broader scale }\end{array}$ \\
\hline \multirow[t]{3}{*}{$\begin{array}{l}\text { Calculating } \\
\text { scores }\end{array}$} & $\begin{array}{l}\text { Normati } \\
\text { ve aspect }\end{array}$ & Experts personal judgment & $\begin{array}{l}\text { Six 'Livability' principles \& users can } \\
\text { adapt weights in the Index } \\
\text { according to their priorities }\end{array}$ \\
\hline & $\begin{array}{l}\text { Objectiv } \\
\text { e aspect }\end{array}$ & City context & $\begin{array}{l}\text { A "place" versus a large } \\
\text { neighbourhood context }\end{array}$ \\
\hline & $\begin{array}{l}\text { Subjectiv } \\
\text { e aspect }\end{array}$ & Neglected & $\begin{array}{l}\text { Intangible qualities that people feel } \\
\text { toward a place or a neighbourhood } \\
\text { (i.e. safe, fun, charming, and } \\
\text { welcoming }\end{array}$ \\
\hline
\end{tabular}

\section{Conclusion}

The study draws attention to the term 'livability' as a controversial, pressing urban concern. Many reports had emerged that underline pioneering attempts in creating livable communities. In addition to, many 'livability' programs had started to occur and despite its existence, there may be an absence of clear agreement on this concept starting from its spelling, passing by its definition and ending up to its know-how; how it could be measured and applied. The ambiguity of the term came from two things. Firstly, it is mispresented with other idiom expressions as 'vitality', 'sense of belonging', and 'liveliness'. Indeed, they are key components in the overall quality of any livable environment, but not the same. A livable place embodied a psychological or emotional dimension (i.e. sense of belonging), and the presence of other people within close proximity and their influence on the functionality and desirability of public places creates an energy (1.e. 'vitality' and 'Liveliness'). Therefore, they do relate because they express the individual behaviour result from the interaction of two features; the environmental and personal; however, could not use interchangeably. Nevertheless, beyond the scale of the individual some social and cultural consensus about what livability means could be concluded from the livability studies and the six livability principles, upon which this study stands on and defines 'Livability' as the suitability of a place for comfortably meeting all of one's daily and long-term needs and desires. The second thing is the different views that likened 'Livability' with concepts as 'sustainability', 'well-being', 'satisfaction', 'quality of life', 'happiness' etc. and that actually complicate the issue further. In fact, there is a reciprocal, mutually dependent relationship between them, but the study clarified that they integrate rather than wrestle. They are concepts related to the urban development process; environmental sustainability and healthy neighborhoods affiliated to the objective side of the process, whereas happiness, well-being, and quality of life more affiliated to the subjective side. 'Livability' plays the intermediate role in addressing these two sides so any try to marginalize the 
role of any concept will complicate the issue further. It is an issue to survey these ideas through the triple-primary concern structure (i.e. environment, economy, and social equity) that is highly affiliated with sustainability because this convenient analytical framework usually focuses attention on the objective side neglecting the subjective one presented in the third dimension (i.e. social equity) and accordingly neglecting happiness, well-being, quality of life, and livability. There is a necessity to the demarcation of concepts. Each must understand separately and had their own indicators. Each concept has different questions that should be asked in trying to achieve, as for redeveloping our communities for sustainability the question will be how to close the loop between input (energy and materials) and output (pollution and wastes), for healthy neighborhood, the question will be what is the health consequence of any urban action. Whereas, for achieving completely subjective aspects as a quality of life, wellbeing, and happiness the question is how individuals and localized communities perceive their situation. For the livable city, the question is how suitable the city is for the living, and here the question is more complex and essential because the answer will be defining the objective measure of the ability of the urban area to enhance the subjective individual quality of life. It is about searching for the exactly what is pleasant to live in specifically for each citizen not merely meeting the minimum standards of habituation otherwise it will not be fulfilled.

The study adopts the viewpoint that the sustainability analytical framework did not provide the right answer to the above question nor did the annual lists or rankings of the 'world's most livable cities'. These 'livability' and benchmarking indices weighted the various global cities against each other in various inclusive categories with various outcome scores. Although they tried to discard the triple-bottom-line framework, unfortunately, the 'standard of living' replaced it, so none of the existing indices takes the perception of the regular user who lives in that city and models this user as having multi-dimensional sensibilities towards different city issues. On the contrary, they targeted investors neglecting to ask how people feel, livability ratings created a gap between objective measures such as material well-being, displayed by GDP per person, and subjective life satisfaction; people's perception. Instead, PPS and AARP had worked on bridging this gap by developing indices that incorporate six principles for livability' and encompass a people-focused remit for the built environment centred on improving quality of life. AARP Livability Index website and PPS Place Diagram tool adopted a bottom-up approach; working on achieving 'livability' on a broader scale through the cumulative improvement of specific places since communities consist of many small areas. In contrast, livability' ranking adopted a top-down approach that works on setting practical strategies at the beginning in order to address ultimately local community concerns.

Although these efforts to measure 'livability' using a range of livability indices, a problem can be encountered that, there is no agreement on what constitutes the most appropriate index, as no designated formula for achieving 'livability' it depends on the context. 'Livability' is in large part a subjective concept; however, enough agreement exists on livability' principles to make this term as useful as a guiding philosophy of urban design and to allow the development of livability guidelines for specific types of places; customizing solutions according to the specific context of a place. The lack of one of these principles can make life much harder. This study is a call to abandon or at least to minimize our dependence on the conventional three pillars of sustainability and livability ranking and to put more emphasis on effective tools like PPS and AARP and even try to innovate over this tools. They are tools that noticeably quantify livability because they involve assessing the concerns and needs of any local community and then using this assessment 
to make improvements to the many places in that community; reflecting the principal attributes that people want in their communities. 'Livability' is about making inhabitants of any place feel good about where they live through studying the human interaction with the built environment. The more there is a study on how people interact with the built environment, with a specific focus on the social, cultural, and psychological dimensions that shape these interactions, the more facilitation in efforts to create a livable urban environment.

\section{References}

[13] Abdel-Hadi, A., Tolba, M. K., \& Soliman, S. (2010a). Sustainable liveability: Privacy zoning as a physical condition for social sustainability. In M. Van Dorst, Environment, health, and sustainable development (Vol. 1, pp. 111-125). Cambridge, MA: Hogrefe Publishing, pp. 111-125, 2010.

[22] Abdel-Hadi, A., Tolba, M. K., \& Soliman, S. (2010b). Environment, health, and sustainable development. In Advances in People-Environment Studies (Vol. 1, pp. 111-125). Cambridge, MA: Hogrefe Publishing.

[38] AIA. (2010). Promoting Livable Communities. (American Institute of Architects) Retrieved from www.aia.org

[16] Allen, T. F. (2010). Making livable sustainable systems unremarkable. Systems Research and Behavioral Science, 5(27), 469-479.

[14] Balsas , C. J. (2004). Measuring the livability of an urban centre: an exploratory study of key performance indicators. Planning, Practice \& Research, 1(19), 101-110.

[32] Barton, H., \& Grant, M. (2006). A health map for the local human habitat. The Journal for the Royal Society for the Promotion of Health, 6(126), 252-253.

[9] Bosselmann, P. (2008). Urban transformation: Understanding city form and design. Island Press.

[24] Campbell, D., \& Oquist, G. (1996). Predicting light acclimation in cyanobacteria from nonphotochemical quenching of photosystem II fluorescence, which reflects state transitions in these organisms. Plant physiology, 4(111), 1293-1298.

[6] Chazal, J. d. (2010). A systems approach to livability and sustainability: Defining terms and mapping relationships to link desires with ecological opportunities and constraints. Systems Research and Behavioral Science 27, no. 5, 585-597.

[29] Competition, V. (2008). A State of Liveability: An Inquiry into Enhancing Victoria's Liveability. Melbourne: Victorian Competition and Efficiency.

[31] Dahlgren, G., \& Margaret, W. (1991). Policies and strategies to promote social equity in bealth. Stockholm: Institute for future studies.

[26] Evans, S., Powell, J., Coghill, N., \& Means, R. (2009). An evaluation of the Gloucestershire partnerships for older people project. Project Report. . University of the West of England. Retrieved from http:// eprints.uwe.ac.uk/7352

[20] Gehl, J. (2013). Cities for people. Island press.

[25] Godschalk, D. R. (2004). Land use planning challenges: Coping with conflicts in visions of sustainable development and livable communities. Journal of the American Planning Association, 1(70), 5-13.

[17] Gough, M. Z. (2015). Reconciling livability and sustainability: Conceptual and practical implications for planning. Journal of Planning Education and Research, no. 2(35), 145-160.

[12] Hankins, K. B., \& Powers, E. M. (2009). The disappearance of the state from "livable" urban spaces. Antipode, 41(5), 845-866.

[33] Hovey, B. (2008). Review Essay: In Search of Urban Livability: CARL ABBOTT, Greater Portland: Urban Life and Landscape in the Pacific Northwest. Journal of Urban History, 3(34), 552-561.

[39] Kent, F. (1997). TCRP Report 22: The Role of Transit in Creating Livable Metropolitan Communities. Transportation Research Board. Washington, DC: National Research Council. Retrieved from http://apps.trb.org/cmsfeed/TRBNetProjectDisplay.asp?ProjectID=1131

[15] Knox, P., \& Heike , M. (2013). Small town sustainability: Economic, social, and environmental innovation. Walter de Gruyter.

[10] Kordjazi, M., \& Mirsaeedy, L. (2014). A Study on Criteria of Vitality and how they affect urban spaces. nternational Journal of Basic Sciences \& Applied Research, 3, 98-103. 
[35] Lennard, S. H., \& Lennard, H. L. (1995). Livable cities observed: a source book of images and ideas for city officials, community leaders, architects, planners and all other committed to making their cities livable. Gondolier Press.

[1] Liveable or livable. (2017, December 10). Retrieved March 16, 2018, from Grammarist: https://grammarist.com/spelling/liveable-or-livable/

[4] Lyndhurst, B. (2004). Livability \& Sustainable Development: Bad Habits \& Hard Choices. London: Final Report for the UK Office of the Deputy Prime Minister.

[40] Markusen, A., \& Gadwa, A. (2010). Creative placemaking. Washington, DC: National Endowment for the Arts.

[3] Merriam Webster. (2018, March 1). Retrieved April 23, 2018, from https://www.merriam-webster.com

[34] Okulicz-Kozaryn, A. (2013). City life: Rankings (livability) versus perceptions (satisfaction). Social Indicators Research, 2(110), 433-451.

[7] Pacione, M. (1990). Urban liveability: a review. Urban geography 11, no. 1 , 1-30.

[5] Pandey, R., Garg, Y., \& Bharat, A. (2014). Quantitative Approach for Understanding Perspectives on Livability in Indian Context. International Journal on Emerging Technologies 5, no. 1(1), 1-7.

[36] Project for Public Spaces (PPS). (n.d.). Retrieved from www.pps.org

[37]American Association of Retired Persons (AARP) . (n.d.). Retrieved from www.aarp.org

[11] Risom, J. (2016, December 27). Livabilitization: Numbing the Urban Experience. Retrieved December 30, 2016, from http://gehlpeople.com/blog/livabilitization-numbing-the-urban-experience

[18] Ruth, M., \& Rachel , F. S. (2013). Livability for all? Conceptual limits and practical implications. Applied Geography(49), 18-23.

[30] Rydin, Y., Ana , B., Michael , D., \& Julio, D. (2012). Shaping cities for health: complexity and the planning of urban environments in the 21st century. The Lancet, 379(9831), 2079-2108.

[27] Szibbo, N. A. (2015). Livability and LEED-ND: The Challenges and Successes of Sustainable Neighborhood Rating Systems. UC Berkeley.

[28] VanZerr, M., \& Seskin, S. (2011). Recommendations Memo\# 2 Livability and quality of life indicators. Portland : $\mathrm{CH} 2 \mathrm{M}$ Hill.

[21] VTPI. (2010). Community livability: helping to create attractive, safe, cohesive communities. TDM encyclopedia. Victoria, Canada. Retrieved from Victoria Transport Policy Institute.

[19] Brundtland, G., and WCED (World Commission on Environment and Developm (1987). Our common future: Report of the world commission on environment and development. Oslo : United Nations.

[23] Wheeler , S. M. (1998). Planning sustainable and livable cities. In Sustainable Urban Development Reader.

[8] Wheeler, S. (2001). Livable communities: Creating safe and livable neigbborboods, towns, and regions in California. UC Berkeley: (IURD) Institute of Urban and Regional Development.

[2] Wiktionary. (2017, July 22 ). Retrieved December 20, 2017, from https://en.wiktionary.org/wiki/livability 